e-ISSN 1980-5918

Fisioter. Mov., Curitiba, v. 30, n. 4, p. 733-744, Oct./Dec. 2017

Licenciado sob uma Licença Creative Commons

DOI: http://dx.doi.org/10.1590/1980-5918.030.004.A008

(c) (i)

\title{
Sexuality and reproduction in women with spinal cord injury
}

\author{
Sexualidade e reprodução em mulheres com trauma raquimedular
}

\author{
Daniella Vieira Ferreira ${ }^{[a]}$, Maria Eliane Liégio Matão ${ }^{[b]^{*}}$ \\ [a] Centro Universitário de Mineiros (UNIFIMES), Mineiros, GO, Brazil \\ [b] Pontifícia Universidade Católica de Goiás (PUC), Goiânia, GO, Brazil
}

\begin{abstract}
Introduction: Spinal cord injury (SCI) is debilitating and results in different social representations for the women affected in terms of their sexuality and reproduction. Objective: Describe the experience of women with SCI regarding sexuality and reproduction under these conditions. Methods: Participants were 11 women with SCI who were submitted to a semi-structured interview. The content of the interviews was inputted into ALCESTE software, a computerized technique used for text analysis. Results: The dendrogram obtained shows two clusters and five subcategories. Cluster I contains issues related to living with SCI and consists of four classes: everyday life, sexuality and reproduction, difficulties, and coping. The so-called class of perceptions is in cluster II, which addresses subjective aspects. The classes in cluster I revealed symbolism associated with sexual relations, reproduction, affective relationships before and after SCI and relationships with the body. The results indicate that sexuality among women with SCI is marked by a mixture of feelings. While they are insecure about expressing themselves sexually, they also report fear of abandonment and loneliness, possibly due to conflicts about accepting their new image, which in most cases was characterized by low self-esteem. Conclusion: The representations of the sexuality and reproduction of the women studied here are vital in the process of accepting and coping with SCI, as well as recovering their social, affective and sexual relationships.
\end{abstract}

Keywords: Sexuality. Reproduction. Women. Spinal Cord Injury.

* DVF: MS, e-mail: daniellafisio@hotmail.com

MELM: PhD, e-mail: liegio@ih.com.br 
Resumo

Introdução: $O$ Trauma Raquimedular (TRM) é marcado por um contexto incapacitante e acarreta diferentes representações sociais para as mulheres acometidas quanto à sua sexualidade e reprodução. Objetivo: Descrever a vivência de mulheres com TRM acerca da sexualidade e reprodução nestas condições. Métodos: Participaram 11 mulheres com TRM as quais responderam uma entrevista semiestruturada. O conteúdo das entrevistas foi submetido ao software ALCESTE, o qual se constitui como técnica computadorizada utilizada para análise de texto. Resultados: $O$ dendograma obtido apresenta dois eixos e cinco subcategorias. $O$ eixo I trata de assuntos pertinentes a vivência nesta condição, sendo contemplado por quatro classes, respectivamente: cotidiano da vida, sexualidade e reprodução, dificuldades e enfrentamento. Já no eixo II, o qual trata dos aspectos subjetivos, está presente a classe denominada de percepções. As classes do eixo I revelaram simbolismos associados ao sexo, reprodução, relações afetivas antes e após o TRM e relações com o corpo. Os resultados encontrados revelam que a vivência da sexualidade da mulher acometida por TRM é marcada por um misto de sentimentos. Ao passo que demonstram insegurança de se manifestarem sexualmente, também referem o medo do abandono e da solidão, possivelmente devido aos conflitos de aceitação da nova imagem, que na maioria dos casos foi caracterizado por auto preconceito. Conclusão: As representações das mulheres aqui estudadas quanto à sua sexualidade e reprodução evidenciam que a sexualidade tem suma importância no processo de aceitação e enfrentamento do TRM, bem como para o resgate dos papeis sociais e afetivo-sexuais.

Palavras-chave: Sexualidade. Reprodução. Mulheres. Traumatismos da Medula Espinhal.

\section{Introduction}

Spinal cord injury (SCI) is damage to the spinal cord resulting from trauma, compression, or total/partial rupture of nerve transmission, which leads to changes in motor, sensory and autonomic function $(1,2)$. The condition does not generally progress to death, but limits and changes the lifestyle of those affected (3), radically altering the lives of families and the experience of living in society (4).

The period immediately after a spinal injury is marked by asexuality, followed by a period of discovery. Adaptation to the new situation is heavily influenced by social and emotional aspects, whereby the individual experiences negative feelings such as anguish, disbelief, anxiety and desperation in the face of resuming a sex life; emotional support and self-esteem are highly significant in this process (5).

The beginning of women's sexual experiences after SCI poses a number of conflicts because they are afraid they will never be able to express themselves sexually. They fear abandonment by their partners or the possibility of never having another relationship; however, these fears soon fade when they begin to accept themselves (6).
The ability to have children is considered important to any woman, both from an emotional and social perspective, as well as physically/physiologically (7). As such, the experience of pregnancy is significant in the context of Brazilian sexual culture and involves complex interactions between men and women (8). People attribute different values to maternity based on their human, spiritual and intellectual experiences (9).

It is important to underscore that amenorrhea occurs soon after trauma during the period of spinal shock, which prevents pregnancy, and varies from one to six months according to the literature. After this period, conditions are once again favorable to pregnancy (10), whereby women are capable of normal fertilization, provided they are monitored and receive the specific care that is essential during pregnancy (11).

In light of the above, how do women with SCI experience sexuality and reproduction? In order to answer this question, the present study aimed to describe the experiences of women after SCI, specifically highlighting their sexuality and reproduction. The intention is to provide support to professionals in order to enhance and strengthen their assistance in coping with SCI. 


\section{Methods}

The study was approved by the Research Ethics Committee of the Pontifical Catholic University of Goiás (PUCGO) under protocol number 922.869. In order to maintain participant anonymity and the confidentiality of the information provided, their statements are identified with the letter $\mathrm{M}$ followed by an ordinal number, according to the order of participation.

Inclusion criteria were being a woman, aged 18 years or older; diagnosed with SCI at least one year previously; active sex life before the trauma and being registered with the Rio Verde Association for the Physically Disabled (ADEFIRV). Women with no medical diagnosis and those without the cognitive ability to express themselves verbally were excluded.

In order to describe the social reality and understand the experiences of women after SCI regarding their sexuality and reproduction, a qualitative descriptive field study was conducted according to the theoretical-methodological assumptions of Social Representations Theory (SRT), a body of practical knowledge centered on communication and understanding the social, material and ideational context that we live in (12).

The SRT framework elucidates how facts occurring in the environment are assimilated, how they are understood by individuals and how the knowledge built based on these facts is expressed through their communication and behavior (13).

To identify potential participants, the electronic files of the institution were examined and medical records analyzed to find data supporting the inclusion and exclusion criteria, resulting in 12 women. A database was compiled at this stage, allowing us to establish initial contact with the eligible subjects identified. Participants were 11 women, since one passed away during the data collection period.

The data collection instrument chosen was a semi-structured interview, at the end of which the SCI-affected women registered with ADEFIRV were asked to participate in the study. A portable recorder was used during the interview and the content of the recordings was transcribed in full to obtain detailed information and ensure its reliability.

The content of the interviews was inputted into Analyse Lexicale por Contexte d'um Ensemble de Segments de Texte (ALCESTE) software, version 4.5, a computerized technique used for textual analysis based on a large number of statistical methods suitable for discourse analysis. The goal is to examine the distribution of vocabulary in written text (14). ALCESTE performs a detailed assessment of the interviews, with each one grouped into a single corpus known as an Initial Context Unit (ICU) and segments of text called Elementary Context Units (ECUs), which are analyzed in descending hierarchical order into word classes from the different discourses on a relevant topic (15). This allows the identification of themed clusters and their respective classes.

The ALCESTE program computes a list of word correlations for each class. This is achieved by adopting chi-squared $\left(\mathrm{X}^{2}\right)$ as a strength of association criterion between the classes, grouping those that exceed this value into a specific class, with higher values indicating greater relevance of the word in constructing the class $(16,14)$. It is important to underscore that interpretation of the core meanings obtained should be based on empirical theory justified by the researchers and supported by other textual and discourse analysis methods $(17,16)$.

In other words, quantitative analysis can be performed based on the contextualization of the symbols within each cluster and their identification. The results of this initial analysis are distributed into clusters with their respective classes, which contain their representative symbols and explainable variance of each class, and can be represented in table or tree (dendrogram) form (15).

\section{Results}

Participants were 11 women with different levels of spinal cord injury between T9 and L2, who were paraplegic as a result of SCI. Time since injury varied considerably, ranging between 2 and 23 years. All subjects were registered with the ADEFIRV and regularly participated in the programs offered by the association.

The corpus submitted to the software for analysis identified 11 ICUs and 231 ECUs. Immediate assessment shows a dendrogram with two clusters and five classes. The corpus was initially divided into two subcorpora, one of which was divided into two, producing class IV. In a subsequent third stage, partitioning generated classes II and III on one side and class V on the other. 
According to hierarchical descending classification, the dendrogram exhibits two clusters and five classers. Cluster I was denominated aspects related to living with SCI based on the content of each of the related classes, namely I, II, III and IV, which addressed everyday life after SCI, sexuality and reproduction, limitations and difficulties, and coping after SCI, respectively. Cluster II, identified as subjective aspects of living with SCI, contains class V, which deals with perceptions after SCI.

Analysis of cluster I showed a focus on objective issues related to life after SCI. It contains situations that require complete adjustment both in terms of the new physical condition, including aspects related to sexuality and reproduction, and how those affected interact with their families and society.

In a more detailed assessment, class I, which contains $16.5 \%$ of the corpus, addresses aspects of everyday life after SCI, focusing more intently on participants M2, M5 and M10. The highest participation percentage is in class II (23.5\%), with information on sexuality and reproduction and contributions from all the subjects, but particularly M6, M7 and M9. Also part of cluster I and comprising $19.4 \%$ of the total corpus, class IV deals with coping after SCI, mentioned primarily by M3, M6 and M8. Class III addresses the many difficulties experienced since the injury, a subject pertaining to $20.6 \%$ of the corpus and highlighted in statements by M1 and M7.

Cluster II contains subjective aspects regarding the situation of participants as a result of SCI, including what other people think and the perception of participants in relation to their condition. This cluster contains class V, pertaining to perceptions after SCI and corresponding to $20 \%$ of the corpus, mentioned primarily by M4 and M11.

Eighteen words were selected from class I, the most frequent being "feel", "go out", "dress up", "pass", "nothing", "always", "not" and "like", relevant in statements from M2, M5 and M10. This class primarily deals with everyday situations after the trauma and resulting from it. The participants report changes to their lifestyle as a result of their physical condition, whether temporary or not, affecting a variety of different areas:

Life after SCI was difficult to adjust to; I had to learn to do everything again, I couldn't even sit up without help. (M2)
After my SCI, everything changed... My routine, activities, friends and goals. Yes..., everything got more difficult in every way! (M4)

Well... In my opinion, you have to learn how to live all over again! (M7)

I am so used to my life after SCI that I consider myself as normal as everyone else. (M11)

SCI undoubtedly requires a number of changes in the everyday lives of these women, some of which focus on the repercussions, to a greater or larger extent, in terms of personal appearance as demonstrated in the statements below:

I have always made an effort with my appearance. Regardless of whether I'm going out or not, I have to get my nails and hair done on the weekend, even if I'm just going to sleep. I don't like looking sloppy. (M2)

Even after my health problem I still care about how I look. I haven't lost that, Thank God! (M3)

Sometimes I couldn't wear a dress because I had to use a back brace... I ended up wearing sneakers because they're more comfortable, that sort of thing... Nowadays I have more freedom when it comes to what I wear. I wear shorts despite my legs; you get self-conscious about your skinny legs. I wear high heels even in my wheelchair. (M4)

I used to dress up every day... I enjoyed it... Not anymore... To me, the world has ended... (M5)

I feel beautiful and I get dressed up, I feel like putting on makeup... (M10)

In class II, 18 words were chosen, with the most frequent being "say", "nowadays", "even", "like this/ that", "think", "not", "never" and "go", evident in statements by M6, M7 and M9.

Initially, this class illustrates experiences related to the love life of participants before SCI:

Before SCI I wasn't in a committed relationship and wasn't very interested in dating. I dabbled here and there, I had several sexual partners and was fine with that. (M7) 
My sex life was never very active... I've never been married and only had boyfriends so I was always more cautious in relation to my sex life. (M8)

My sexuality was better before the injury; you feel more attractive, more loved... (M9)

Next, the interviewees highlighted aspects of their sexuality and sexual intercourse itself after SCI:

I never had sex again after the injury. I don't feel any sexual desire. Not at all... For example, I'm in a wheelchair, but if that was my only problem I might even consider it! After I became like this, my life stopped. I can't control my bladder, I have to use a diaper, and so many other things... (M1)

I don't have a love life because I'm single at the moment. My experience with sexuality has changed because now I have limitations. Limitations in terms of position, and because one of my lungs collapsed; only one of them actually works, so sometimes I get out of breath... Always! (M2)

Unfortunately, after my illness my husband cheated on me with another woman while I was in hospital. He passed away soon after that. It was difficult to deal with the pain of that betrayal at a time when I was really in need. (M3)

I never had any problems in terms of sex... I even broke the taboo because I had imagined a million different things in my head but it ended up not being that bad. Just as well, thank God, but that also depends on who you're with, and you have to surrender; you end up surrendering little by little and the other person has to understand you [...] Today I'm not dating, but you meet people here and there... The resource I use to satisfy myself sexually is really the same as any couple would use!! (M4)

Well... My love life... My husband is amazing, he's so good to me, but he's just not interested in me sexually anymore... You know?! Because when I had the accident it was right when we were... I was doing something to him... You know... So... He's just not interested anymore... (M6)

My love life is good... I'm married now, it'll be six years in March... I met my husband and we quickly became a couple. For me it was easy, he accepted me, I never had any problems. Sometimes a certain position or something will hurt me, but he's never been bothered by my condition... (M7)

My sex life after the injury has been non-existent... At the moment, I'm not using any strategies, I'm completely inactive in terms of a sex life... You feel desire, but I'm not interested in using resources to satisfy it... I have no desire for sex itself... (M8)

I have no desire for sex! Not anymore. Nowadays I don't feel attractive because of the injury... There are so many limitations, so many things I did before that I can't do anymore, that are impossible to do... (M9)

I used to just lie around, I was depressed because my husband would go out... Eventually I couldn't take it anymore and filed for divorce; I went to live with my mother and am still living with her. (M11)

They indicate relationships and opinions regarding acting on their sexuality that demonstrate fragility and vulnerability in the face of their physical condition.

I never found anyone, there's nobody who would want me like this... (M1)

Men have this idea of women with big breasts, nice legs, large buttocks, women in high heels, you know? In a wheelchair, you don't have that... You only have your natural beauty! You have your charisma, but men can't see that. [...] (M4)

After the injury, it was difficult because I was scared; you feel afraid because sex is so intimately related to the body, so you're frightened because your whole body has changed. Now you have a scar, you can't move, so things are much more difficult. I went almost a year and a half without having sex at all. Then I met someone at SARAH (SARAH network of Rehabilitation Hospitals) who was also wheelchairbound and we started dating. He was the first person I had been with after my injury because I thought he would accept me since he also used a wheelchair. After that I had a short relationship with a classmate from university who is able bodied, and there were no problems for me, or for him I think; it was very similar to relationships I had before the injury. (M7) 
My love life is terrible... I'm not seeing anyone. At the moment, it's difficult to move around, you know?! So, I'm not going to pursue that... Nowadays I don't feel attractive anymore, because of the injury... (M9)

It is evident that some women, albeit a minority, report having an active sex life without major difficulties.

Even in my physical condition my love life is great! In terms of my sexuality after the injury, it was normal from the start because I was married and both my husband and I adjusted easily. I'm currently dating and my sex life is better than ever! (M11)

Most participants report the absence of a sex life, and at times, sexual desire itself:

I never had sex again after the injury. I don't feel any sexual desire. (M1)

I have no desire for sex... So, I don't use anything... Since my husband died I have never been interested in finding someone else. (M5)

I have no desire for sex... I just don't' think it's necessary... (M9)

In addition to sexuality, the women in this class identified issues related to reproduction, as indicated in the statements below:

My daughter was born prematurely 10 years after my injury... [...] It was the 10-year anniversary of my injury on March 15, and my daughter was born a week later on March 22. I found out I was pregnant at 30 weeks and she was born at 33 weeks. I had no symptoms of pregnancy and could wear my normal clothes! My stomach didn't get bigger, I didn't have cravings... The delivery was dangerous because I had lost all my amniotic fluid thinking I was just urinating. I couldn't feel anything and thought everything was fine, but it was already well past the time to deliver the baby... (M2)

You see your married friends having children, my sister is dating someone, so nowadays it's really, really, really difficult for me, especially if the people where you live are narrow-minded. (M4)
For me being a mother is great [...] if it were up to me, my own desire, I'd have another child... (M8)

I don't think I'll have children... Nowadays I have too many limitations so I don't want to; I don't think children are a good idea at the moment... (M9)

I don't want to have children... (M10)

Twenty words were selected in class III, with those most used including "look after", "want", "because", "adjust", "think", "not" and "go", highlighted by M1 and M7.

This class reveals a range of limitations and difficulties.

People with disabilities face countless difficulties every day. Accessibility is definitely the biggest problem. (M3)

The greatest difficulty is accessibility, 100\%. (M7)

It's difficult because of the tiredness... Moving around. Adjusting to wherever you are. (M10)

The above statements on the difficulties experienced after SCI are noticeably negative. In general, the women affected indicated lack of accessibility as one of the main factors.

Dependence and prejudice, whether on the part of others or themselves, is also emphasized by the interviewees.

In terms of difficulties, the thing I find most difficult is not being able to look after myself and everything. (M1)

In terms of difficulties, it's not being able to move and all that... Oh... Having to depend on my husband... For example, if I need to take a shower... 'Honey, I want to shower', 'Hang on'.... Then I have to wait... and wait... I have to wait until it's convenient for him! I can't do anything myself, you know?!... My husband does everything... The only thing I can do is make lunch and even then, it's a battle... (M6)

As soon as I found out about the problem I became very self-conscious and that made it difficult. (M8)

I think my divorce was very difficult. Having to move out of my house into someone else's... (M9) 
In class IV, 19 words were chosen and the most common were "go back", "everything", "especially", "same", "more/most", "take", "very" and "a lot", emphasized by M3, M6 and M8.

Statements in this class provide accounts of coping with the physical condition resulting from SCI, with family support emerging as particularly important:

The main factor that helped me was my family... They helped me a lot! (M3)

What helped me the most in adjusting after the injury was my family... (M7)

Well, I got a lot of support from friends and family, especially my mother. She was with me the whole time... (M8)

No less significant were reports of other forms of support used to cope after the injury.

Wheelchair basketball was also vital... Interacting with people with the same problem, you know! (M3)

Second was SARAH, which provided me with an environment I felt more comfortable in. The people I met there... Experiences exchanged... (M7)

The most important thing after the injury was my physiotherapist, who helped me have more independence... It really helped me a lot... You think you won't be able to do anything... So, you need to have a lot of willpower. (M9)

In addition to the above statements, religious belief and faith in God also feature in the process of coping with and accepting the new lifestyle:

God is always with me and does what is best for me; He gave me my daughter! I love sleeping with her next to me; she has her own room, but she has slept with me since she was born. I found the love of my life... (M2)

What helped me was joining an Evangelical church, otherwise I would have hit rock bottom... (M6)

In first place is God, for giving me another chance. (M8)

Finally, 20 words were selected in class V, of which eight were emphasized, namely "live", "use", "limit", "understand", "affect", “also", "so", and "still”, highlighted by M4 and M11.

In this category, participants reveal something close to the subjective dimension of the problem experienced, emphasizing reflections and symbolic impressions formed in the reality resulting from SCI:

Some people in my life walked away when they saw all the difficulties I had. I think that's why I try not to get close to anyone anymore. Sometimes, people see me in my wheelchair all dressed up and they think it's easy, but when they see the everyday difficulties they realize it's not and walk away. (M2)

There are times when you feel great and at others you feel terrible, not because you're in a wheelchair, but because of how you feel when you go out in a wheelchair and see how people look atyou. How you feel at a certain time depends on other people. (M4)

I became much humbler you know?! Because I used to be very arrogant! I stopped doing a lot of things... Lots of things I was sick of... Life should be simpler. The only difficulty I have... I don't feel that joy anymore since I had the accident, that lust for life... That's all! (M6)

So, the people I am closest to often tell me 'you know, sometimes I even forget about the wheelchair'; so, it's normal, and even I forget that I'm wheelchair-bound sometimes. (M7)

The prejudice against me! Because... As soon as I found out about the problem I became very selfconscious and that made it difficult. (M8)

The bad side, what makes it difficult, is that people think you're an animal. (M11)

\section{Discussion}

Cluster I in the dendrogram, which addresses objective aspects of living with SCI, contains classes I, II, III and IV, which refer to everyday life after SCI, sexuality and reproduction, limitations and difficulties, and coping after SCI, respectively. Class I shows accounts of everyday situations, such as the complexity of tasks previously considered simple. Some participants experienced a change in their behavior, particularly in 
the face of the new routine required due to the limitations imposed by their condition. In a study by França et al. (18), the author highlighted the fact that most participants were dissatisfied with the execution of activities of daily living such as getting dressed, dressing up, eating and personal hygiene tasks because of their dependence and loss of autonomy.

Following SCI, people experience a sudden change in their daily routine. The differences between life before and after the injury make it difficult to accept, coupled with guilt and embarrassment about their dependence on others for personal hygiene tasks and difficulty controlling physiological needs, thus affecting quality of life (19).

Aspects related to personal appearance indicate a concern with their new image, as well as perceptions regarding leisure. Maia (20) reported changes in everyday routines after injury and referred to the adjustments needed due to reduced ability, as well as issues related to affective relationships. Women with disabilities are more severely affected in terms of standards of beauty and esthetics than men, which implies greater difficulty in rebuilding their self-image. Venturini, Decésaro and Marcon (21) observed that the most common difficulties encountered in everyday life are related to financial issues, dependence, lack of the necessary physical infrastructure in the city, transport, employment, physical activity and prejudice.

França et al. (22) found a large number of complaints regarding leisure activities, since in addition to their physical limitations, those affected also encountered structural obstacles in locations visited, as well as on public transport. Other negative aspects mentioned were financial difficulties, prejudice and low self-esteem.

With respect to sexuality and reproduction, covered in class II, the subjects provide accounts of situations experienced in romantic relationships, sexuality itself, and difficulties in the physical recovery process as well as sexual activity. Initially, participants reported they understood the importance of sexuality and that they were more confident before the injury. This corroborated the findings of Singh and Sharma (23), whereby most subjects recalled they were interested in sex and understood its importance in everyday life.

According to the accounts provided in the present study, the difficulty in acting on and/or expressing sexuality after spinal cord injury is related to the physical limitations of the condition and awareness of these constraints. This affects personal relationships due to their inability to meet the standards of beauty and perfection established by society. Kreuter et al. (24) highlight the need for an approach that considers the physical, psychological and interpersonal conditions of these women. Many of them remain sexually active, but report occasional dissatisfaction after SCI, an aspect which should be addressed in rehabilitation. Although several studies indicate that sexual satisfaction is an important factor in quality of life, it is often relegated to the background after SCI (25).

França and Chaves (26) observed attitudinal barriers as a result of the limitations and prejudices imposed by SCI. The authors found that most women with SCI, specifically paraplegia, have difficulty understanding and articulating their feelings about their bodies after the injury because they feel unattractive. This is due to low self-esteem and self-discrimination, evident in their fear of sexual frustration as a result of their physical condition, characterized as abnormal and disabled. In terms of sexuality related specifically to the sexual act, participants emphasized their fear of being intimate with their partners.

Carneiro (27) obtained accounts from women who admitted that new values are imposed for sexuality in their first sexual experience after SCI.

Some participants reported an active and satisfactory sex life despite their limitations, including position restrictions, neurogenic bladder, and dyspnea, while others experienced difficulty readjusting to their partners. With respect to strategies used to satisfy their sexual needs, all participants reported contact with a single sexual partner. In a study by Maia (20), subjects expressed their fears and difficulties in terms of a sex life after injury, but developed greater intimacy with their partners beyond the sexual act itself. They also reported feeling desire and pleasure in romantic and sexual relationships, as well as the use of techniques to assist in sexual relationships and satisfaction. Singh and Sharma (23) observed that half of the women studied reported sexual satisfaction after injury, although some felt their partners were not satisfied.

In the present study, most subjects were not sexually active and at times reported a lack of sexual desire itself. This is similar to the findings of Singh and Sharma (23), whereby subjects labelled their sex lives as worse after SCI, largely due to difficulties in their relationship with their partner, medical problems and the lack of privacy. 
In a study by Fritz, Dillaway and Lysack (28), dissatisfaction with sexual activity was observed in interviews with both married and single women, indicating that being in a committed relationship does not always ensure sexual satisfaction.

A participant in an investigation conducted by Carneiro (27) expressed difficulties coping with muscular atrophy, as observed in the present study. This is likely due to society's belief that a perfect body is a sign of sexual competence, while an imperfect physique is considered asexual.

Cavalcante et al. (12) found that relationships established after SCI when patients have a stronger selfimage tend to be more stable because their romantic partner did not participate in the complex rehabilitation and only needed to adjust to the relationship.

Kreuter et al. (24) observed that most women continued to enjoy an active sex life after their injury and still considered sex an important part of their lives. Although many aspects of their sexual function and sex life were negatively affected, participants in our study used different methods to compensate for the physiological deficiencies caused by the injury.

In regard to reproduction, most felt it is a normal part of a woman's life and therefore vitally important for female satisfaction. However, some viewed it solely as bearing children.

It is important to underscore that one participant who became pregnant after SCI made it clear that her partner had abandoned her and their daughter. Mitra et al. (29) explains that in some cases, the partners of women with disabilities show negative attitudes after delivery, making these women more prone to postpartum depression. Signore et al. (30) report that being a single parent can be difficult.

Another participant also reported a premature birth and the fact that the pregnancy itself had gone unnoticed. Signore et al. (30) found a rise in premature birth rates among women with SCI, in addition to stress, mood swings, and social, economic and physical obstacles.

The participants expressed the importance of pregnancy and viewed it as part of women's social role. Murthy, John and Sagar (31) concluded that reproductive health and pregnancy are equally important to able-bodied women and those with disabilities and is considered invaluable to the latter because it allows them to be perceived as any other women.

In class III, pertaining to the limitations and difficulties caused by SCI, participants describe difficulties in terms of accessibility, moving around and interacting in areas without the facilities to cater to those with disabilities. They also report dependence and self-consciousness in light of their physical condition, including difficult-to-accept situations. Lack of accessibility is a reality for these patients, making them feel even more excluded and restricted. Despite nationwide legislation requiring wheelchair accessibility on streets, in buildings and urban spaces and on public transport, this often does not meet the real needs of those affected, making travel and social inclusion difficult (32).

A study by Carneiro (27) demonstrated the difficulties women with SCI faced in having to depend on family members. This causes embarrassment and hampers the rehabilitation process as a whole, particularly from an emotional perspective. The period of adjustment to SCI is marked by a number of situations, which do not prevent these individuals from continuing to pursue their goals and achieve better quality of life (33).

With respect to coping, family is undoubtedly of unparalleled importance in these conditions. An investigation by Borges et al. (34) indicates that family plays a vital role in the self-perception of people with SCI. Thus, values, beliefs and interaction with others are important and necessary for these individuals, and reflect on their experiences.

Furthermore, activities that allow interaction with people in the same condition, whether in the form of sports or rehabilitation, as well as religious faith, provide an important means of support and are cited as vital by those studied here. Puerari et al. (33) highlight rehabilitation as a form of support during the adjustment process in that it provides functional independence and therefore better self-esteem and social inclusion.

The strategies most frequently used during the adjustment process include religious faith, fantasizing and positive thinking (35), with subjects in the present study specifically citing religion as a support strategy.

According to Puerari et al. (33), family and social integration, psychological and medical care and rehabilitation promote self-care and the pursuit of independence. In terms of better health conditions, those suffering from SCI demonstrated a desire to adjust to their new situation and improve their self-esteem, self-confidence and self-help abilities. Affection and sexual expression encouraged by friends and family favored the recovery of 
self-esteem. The support of family, friends and professionals involved in the clinical case help those affected rebuild their new social identity (20).

Cluster II contains class V, which addresses the subjective aspects of patients in light of their condition, including feelings of sadness, prejudice and in some cases, determination. Rodriguez et al. (36) found that woman with physical disabilities were twice as prone to depression. Additionally, the author reports that this so-called dual disadvantage may result in greater discrimination, since these women are unable to live up to the image standards demanded by society. Married women with SCI and those with an elementary school education were at greater risk of depression.

França et al. (18) observed negative perceptions among patients with SCI regarding their activities of daily living, since the condition impaired performance in sexual relations, at work and in leisure activities. Historical and cultural influences mean there is still a stigma and negative values surrounding the body as a result of SCI (37). The accounts reported by Costa et al. (38) illustrate the experiences of people affected by SCI in terms of their everyday routine and the adjustments needed due to the changes to their bodies. These individuals construct new concepts and meanings for their own conceptions, based on their everyday experiences.

\section{Conclusion}

Representations of the women studied here in terms of their sexuality and reproduction portray a context characterized by physical disability. They demonstrate that sexuality is vital in the process of accepting and coping with SCI, as well as recovering social, affective and sexual relationships. Accounts that highlighted the importance of reproduction for women in general, before and after SCI, were also prominent.

The results indicate that sexuality among women with SCI is marked by a mixture of feelings. While they are insecure about expressing themselves sexually, they also report fear of abandonment and loneliness, possibly due to conflicts about accepting their new image, which in most cases was characterized by low self-esteem.

Working with such complex issues poses a significant challenge, particularly those subject to taboos and prejudice, making it difficult to understand the particularities of sexuality among women with SCI.
Another barrier is the scarcity of accounts pertaining to experiences with this issue, with prejudice and discrimination contributing to the continued view of these women as asexual.

A limitation of this study is the difficulty displayed by participants when talking about the issue, given its highly personal and intimate nature. Thus, further research is suggested to address the aspects involved in the sexuality and reproduction of women after SCI, since the information obtained could contribute to educational and healthcare initiatives to improve the quality of life of those affected.

\section{References}

1. Sartori NR, Melo MRA. Necessidades no cuidado hospitalar do lesado medular. Medicina. 2002;35:151-9.

2. Sodré PC, Faro ACM. Estudo sobre as alterações da função sexual em mulheres com lesão medular resistentes na cidade de Ribeirão Preto/SP. Acta Fisiatr. 2008;15(3):149-55.

3. Murta SG, Guimarães SS. Enfrentamento à lesão medular traumática. Estud Psicol. 2007;12(1):57-63.

4. Campos MF, Ribeiro AT, Listik S, Pereira CAB, Andrade Sobrinho J, Rapoport A. Epidemiologia do traumatismo da coluna vertebral. Rev Col Bras Cir. 2008;35(2):88-93.

5. Garrett A, Teixeira Z, Martins F. Modelo transaccional do stresse: Período que antecede ao reinicio da sexualidade do lesionado vértebro-medular. RFCHS. 2007; 24(4):222-28.

6. Carneiro VMB, Neves EM, Abreu SB, Brito LMO. Sexualidade em mulheres com lesão na medula espinhal. Rev Pesq Saúde. 2012;13(1):30-3.

7. Carvalho APF, Costa VSP, Costa Filho RM, Oliveira LD, Oliveira PS. Gravidez em mulheres com trauma medular prévio. Femina. 2010;38(1):7-11.

8. Heilborn ML. Articulando Gênero, Sexo e Sexualidade: diferenças na saúde. In: Goldenberg P, Marsiglia RMG, Gomes MHA (Org.). 0 Clássico e o Novo: tendências, objetos e abordagens em ciências sociais e saúde. Rio de Janeiro: Editora Fiocruz; 2003. p. 197-208.

9. Oriá MOB, Ximenes LB. Infertile Couple Pursuing for a Desired Child - a clinical case study. Online Braz J Nurs. 2006;5(2). 
10. Bughi S, Shaw SJ, Mahmood G, Atkins RH, Szlachcic Y. Amenorrhea, Pregnancy, and Pregnancy Outcomes in Women Following Spinal Cord Injury: A Retrospective Cross-Sectional Study. Endocr Pract. 2008;14(4):437-41.

11. Cavalcante KMH, Carvalho ZMF, Barbosa IV, Rolim GA. Vivência da sexualidade por pessoas com lesão medular. Rev RENE. 2008;9(1):27-35.

12. Jodelet D. La representación social: Fenómenos, concepto y teoría. In: Moscovici S (org.). Barcelona: Psicologia Social; 1985. p. 469-94.

13. Silva SED, Camargo BV, Padilha MI. A Teoria das Representações Sociais nas pesquisas da Enfermagem brasileira. Rev Bras Enferm. 2011;64(5):947-51.

14. Kronberger N, Wagner W. Palavras-Chave em Contexto: análise estatística de textos. In: Bauer MW, Gaskell G. Pesquisas Qualitativa com Textos, Imagem e Som. Petrópolis: Vozes; 2002.

15. Camargo BV. ALCESTE: um programa informático de análise quantitativa de dados textuais. In: Moreira ASP. Pespectivas teórico-metodologicas em representações sociais. João Pessoa: Editora Universitária; 2005. p. 511-39.

16. Campos PHF, Torres ARR, Guimarães SP. Sistemas de representação e mediação simbólica da violência na escola. Educação e Cultura Contemporânea. 2004;1(2):109-32.

17. Miranda DB, Bortolon FCS, Matão MEL, Campos PHF. Parto normal e cesária: representações de mulheres que vivenciaram as duas experiências. Rev Eletrônica Enferm. 2008;10(2):337-46.

18. França ISX, Coura AS, Sousa FS, Almeida PC, Pagliuca LMF. Qualidade de vida em pacientes com lesão medular. Rev Gaúcha Enferm. 2013;34(1).

19. Rodrigues FCP, Antunes DA. Considerações sobre o paciente com lesão raquimedular ou vítima de trauma: um estudo qualitativo. Nursing. 2010;13(150):573-9.

20. Maia ACB. A Sexualidade Depois da Lesão Medular: Uma Análise Qualitativa-Descritiva de Uma Narrativa Biográfica. Interação Psicol. 2012;16(2):227-37.

21. Venturini DA, Decésaro MN, Marcon SS. Alterações e expectativas vivenciadas pelos indivíduos com lesão raquimedular e suas famílias. Rev Esc Enferm USP. 2007;41(4):589-96.
22. França ISX, Coura AS, Ramos APA, Oliveira CP, Sousa FS. Percepción de adultos con lesión medular sobre las habilidades para actividades diarias y indicación de salud a la luz de la NOC: pesquisa descriptiva. Online Braz J Nurs. 2011;10(2).

23. Singh RMS, Sharma SCMS. Sexuality and Women with Spinal Cord Injury. Sex Disabil. 2005;23(1):21-33.

24. Kreuter M, Taft C, Siösteen A, Biering-Sørensen F. Women's sexual functioning and sex life after spinal cord injury. Spinal Cord. 2011;49(1):154-60.

25. Vaz IM, Coelho MA. Sexualidade e a Lesão VertebroMedular. Acta Urol. 2010;27(2):49-59.

26. França ISX, Chaves AF. Sexualidade e paraplegia: 0 dito, o explícito e o oculto. Acta Paul Enferm. 2005;18(3):253-9.

27. Carneiro VMB. Vivências da sexualidade: atualizações e persistências nos discursos de mulheres com lesão na medula espinhal [master's thesis]. São Luís: Universidade Federal do Maranhão; 2007.

28. Fritz HÁ, Dillaway H, Lysack CL." Don't Think Paralysis Takes Away Your Womanhood": Sexual Intimacy After Spinal Cord Injury. Am J Occup Ther. 2015;69(2):1-10.

29. Mitra M, Iezzoni LI, Zhang J, Long-Bellil LM, Smeltzer SC, Barton BA. Prevalence and risk factors for postpartum depression symptoms among women with disabilities. Matern Child Health J. 2015;19(2):362-72.

30. Signore C, Spong CY, Krotoski D, Shinowara NL, Blackwell SC. Pregnancy in women with physical disabilities. Obstet Gynecol. 2011;117(4):935-47.

31. Murthy GV, John N, Sagar J. Reproductive health of women with and without disabilities in South India, the SIDE study (South India Disability Evidence) study: a case control study. BMC Womens Health. 2014;14(146):1-7.

32. Silva ALL. (Trans) Formação de subjetividades após lesão medular: em direção à hermenêutica do sujeito [master's thesis]. Fortaleza: Universidade Federal do Ceará; 2012.

33. Puerari PBP, Amaral RB, Migott AMB, Prigol AP, Moraes VLM. A autoestima e a autoimagem da pessoa com lesão na medula: relato de experiência de um projeto de extensão. VI mostra de pesquisa e pósgraduação. Passo Fundo: IMED; 2012. 
34. Borges AMF, Brignol P, Schoeller SD, Bonetti A. Percepção das pessoas com lesão medular sobre a sua condição. Rev Gaúch Enferm. 2012;33(3):119-25.

35. Pereira MEMSM, Araújo TCCF. Enfrentamento e reabilitação de portadores de lesão medular e seus cuidadores. PSICO. 2006;37(1):37-45.

36. Rodríguez MÁA, Carenas LG, Gómez YF, Arias BB, Díaz ALA. Proceso de adaptación en mujeres con lesión medular: relaciones entre variables psicológicas y sociodemográficas. Aquichán. 2014;14(2).

37. Rodrigues FCP, Antunes DA. Considerações sobre o paciente com lesão raquimedular ou vítima de trauma: um estudo qualitativo. Nursing. 2010;13(150):573-9.
38. Costa VSP, Melo MRAC, Garanhani ML, Fujisawa DS. Social Representations of the Wheelchair for People with Spinal Cord Injury. Rev Latino-Am Enfermagem. 2010;18(4):755-62.

Received in 27/05/2016

Recebido em 27/05/2016

Approved in 18/04/2017 Aprovado em 18/04/2017 